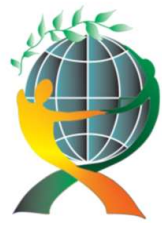

\author{
(online) $=$ ISSN $2285-3642$ \\ ISSN-L = $2285-3642$ \\ Journal of Economic Development, Environment and People \\ Volume 8, Issue 2, 2019 \\ URL: http://jedep.spiruharet.ro \\ e-mail: office jedep@spiruharet.ro
}

\title{
Rohingya-The Stateless Community Becoming the Lost Generation
}

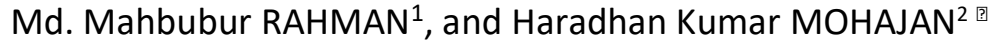 \\ ${ }^{1}$ News Producer, Bangladesh Television (BTV), Adjunct Faculty, University of Development Alternative \\ (UODA), Bangladesh \\ ${ }^{2}$ Assistant Professor, Premier University, Chittagong, Bangladesh
}

\begin{abstract}
The Rohingya is a Muslim ethnic minority group in Rakhine State of Myanmar. It is now established but controversial fact that the Rohingya is a stateless population of the world who has found shelter across vast swathes of Asia mainly in Bangladesh, and also in India, Pakistan, Thailand and Malaysia. But a majority of Rohingyas are living in various camps of Bangladesh with statelessness identity. Recently, the UN warns that the Rohingya children who are living in various camps of Bangladesh would be the lost generations of the world. This article discusses the aspects of "stateless community" and "lost generation" of the world's most persecuted people-the Rohingya.
\end{abstract}

Keywords: Statelessness, Lost Generation, Rohingya

JEL Codes: B30, B55.

How to cite: RAHMAN, M., \& MOHAJAN, H. (2019). Rohingya-The Stateless Community Becoming the Lost Generation. Journal of Economic Development, Environment and People, 8(2), 24-36. Doi: http://dx.doi.org/10.26458/jedep.v8i2.621

\section{Introduction}

Myanmar (The Republic of the Union of Myanmar) is an independent country in the Southeast Asia. Its official language is the Burmese. Naypyidaw (former Yangon) is its capital city. Its total area is 261,228 square miles with populations 60,584,650 (Demographics of Myanmar, 2018). In the 1947 Constitution, the name of the country was Burma, and in 1989, the country was renamed as Myanmar (Ullah, 2011).

Rakhine (formerly Arakan) is one of the poorest State of Myanmar with area 14,200 square miles where most of the Rohingyas live. It is situated at the border region of Myanmar's western coast (Islam, 1999). The Rohingyas are the most ill treated community of the world having lived in a realm of statelessness for generation to generation (Milton et al., 2017). The Rohingya Muslims are the ethnic people without a State.

Corresponding Author. Tel/Mobile Phone: + 8801716397232;

E-mail address: haradhan1971@gmail.com 


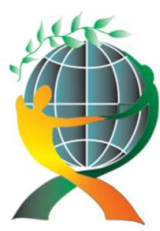

\author{
(online) $=$ ISSN $2285-3642$ \\ ISSN-L = $2285-3642$ \\ Journal of Economic Development, Environment and People \\ Volume 8, Issue 2, 2019 \\ URL: http://jedep.spiruharet.ro \\ e-mail: office jedep@spiruharet.ro
}

For years they have been living in the Northern Rakhine province of Myanmar but the Government of Myanmar (GoM) or any other country of the world does not identify the Rohingya as citizens. The 1982 Citizenship Law has been deprived the Rohingya from the citizenship of Myanmar (Abdelkader, 2014).

Being displaced over multiple generations increase the vulnerability of the Rohingya as statelessness. Again the Rohingya children born in abroad (Bangladesh or elsewhere) remain as stateless citizens. In one year anniversary of Myanmar military crackdown on Rohingya Muslims on 25 August 2018 the UNICEF warned that the Rohingya kids could become a "lost generation" (UN, 2018).

\title{
2. Literature Review
}

Many researchers argue that the present Rohingya crisis is based on the citizenship status of the Rohingya. The GoM does not recognize the Rohingya as citizens, and a majority of the Muslims living still in Rakhine State are de facto stateless and living with a deep uncertainty about their status though the Rohingya ancestors have been living in Rakhine State since the $8^{\text {th }}$ century with full citizenship (Bellamy, 2016; Holliday, 2014; Ruland, 2017).

In postcolonial age the countries in South-East Asia used the concept of "indigeny" to distinguish the local inhabitants from outsiders (Parashar \& Alam, 2018). Ardeth Maung Thawnghmung reveals how the Rakhine Buddhists and Muslims rely on the concept of "indigeneity" to assert their claims as citizens (Thawnghmung, 2016). Samuel Cheung observed that the Rohingyas were excluded from the list of ethnic minority group by Burmese 1982 Citizenship Law (Cheung, 2012). Mahbubul Haque stated that the Burmese 1982 Citizenship Law institutionalized the Rohingyas statelessness (Haque, 2017). Nyi Nyi Kyaw argues that policies and practices of successive GoMs (from the late 1970s) make the Rohingyas as chronic stateless (Kyaw, 2017).

Matteo Fumagalli pointed out that the silence of Myanmar State counselor Aung San Suu Kyi increases the plight of statelessness of the Rohingya (Fumagalli, 2018). With a different focus Benjamin Zawacki argues that the GoM allowed the Rohingya from Bangladesh through repatriation in 1991, allowing them to vote in 1990, 2008, and 2010 which proved some of the status of citizenship of the Rohingya (Zawacki, 2013). Samak Kosem and Amjad Saleem agree that Rohingya citizenship is a state-societal and ethno-territorial issue that requires a comprehensive study (Kosem \& Saleem, 2016).

Haradhan Kumar Mohajan has discussed the origin of the Rohingya Muslims and the history of Rakhine State. He has stressed that Rohingyas are deprived from their fundamental human rights and they are victim of genocide in Myanmar (Mohajan, 2018a, b; 2019). Adrian Ştefan Ene indicates the state aid in the current national and international economic context which can be applied for the aid of the Rohingya (Ene, 2016).

\section{Methodology of the Study}

The methodology of a research indicates the logic of development of the process used to generate theory that is procedural framework within which the research is conducted (Remenyi et al., 1998). The data are collected to achieve the result for the purpose and scope of this study. The methodology of this article is to discuss the sufferings of the stateless Rohingya. In the study we have observed that the 


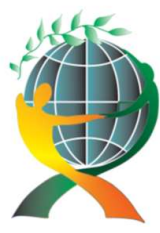

\author{
(online) $=$ ISSN $2285-3642$ \\ ISSN-L = $2285-3642$ \\ Journal of Economic Development, Environment and People \\ Volume 8, Issue 2, 2019 \\ URL: http://jedep.spiruharet.ro \\ e-mail: office jedep@spiruharet.ro
}

Rohingya is becoming lost generation due to the deprivation of the nation from education and other human rights.

For this article we have reviewed various documents pertaining to the Rohingya crisis. Mainly secondary data have been used to prepare this article. For the collection of secondary data we have used both published and unpublished data sources. The published data are collected from books of various authors, hand books, theses, magazines, newspapers, journals, websites, historical documents, and research reports. The unpublished data are collected from many sources, such as diaries, letters, unpublished biographies and autobiographies, and also from the documents of scholars and research workers (Mohajan, 2018c).

In the study we have analyzed aspects of Rohingya migration problems, such as origin and the historical background of the Rohingya, inhuman torture to them by the GoM and carelessness from the Governments of the migrated countries, why they become stateless, etc. In the study we have observed that due to political oppressions Rohingyas are becoming lost generation.

\title{
4. Objective of the Study
}

In this study we try to discuss the history of statelessness of the Rohingya and also the danger of becoming a lost generation of Rohingya children. Some other objectives of the study are:

- to define the scenario how statelessness changing into lost generation,

- to provide the historical evidences of statelessness of Rohingyas, and

- to highlight the stages of statelessness.

\section{The Word "Rohingya" Ignored by GoM}

"Rohingya" is a generic term used for the Muslim inhabitants of Arakan State of Myanmar. Though the term "Rohingya" is used by the world community but the GoM does not even use the term 'Rohingya' instead call the community as Bengalis, immigrants, foreigners or terrorists. The present de facto leader of Myanmar Aung San Suu Kyi also refused to use the term 'Rohingya' (Gibson, 2016).

During the Asia tour of Pope Francis in Myanmar in December 2017, the religious leader Pope was asked by the GoM not to use the term 'Rohingya' and Pope did not use the term 'Rohingya' in his Myanmar visit. Pope came from Myanmar to Bangladesh and at that time he for the first time used the term 'Rohingya' (Rahman, 2017).

Rohingyas described as distinctive due to their religion, customs and physical features. They practice a "Sufi-inflected" version of Sunni Islam and the "Rohingya" is the only their spoken language (Holliday, 2014). The word "Rohingya", also known as Rwangya, is derived from the ancient name for Arakan 'Rohang', while some believe that it is the corrupt form of an Arabic term 'Raham' meaning 'sympathy'. According to Khin Maung Yin, "It is said that an Arab ship was wrecked near the coast of Arakan and the illfated people took refuge in Arakan by uttering the word 'Raham' meaning 'compassion'. The locals pronounced it as Rohang; since then the people living there are known as the Rohingyas" (Yin, 2005).

Experts say the label of Rohingya provides the group with a collective, political identity. Even though the etymological root of the word is disputed, the mostly accepted origin is that the "Rohang" that is a 


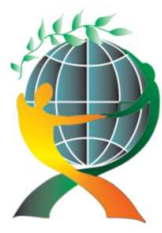

\author{
(online) $=$ ISSN $2285-3642$ \\ ISSN-L = $2285-3642$ \\ Journal of Economic Development, Environment and People \\ Volume 8, Issue 2, 2019 \\ URL: http://jedep.spiruharet.ro \\ e-mail: office jedep@spiruharet.ro
}

derivation of the word "Arakan" in the Rohingya dialect and the "ga" or "gya" means "from". By identifying themselves as Rohingya, the ethnic Muslim minority group asserts its ties to the land that was once under the control of the Arakan kingdom (Tennery, 2015).

\title{
6. Historical Background of the Rohingya
}

The history of the Rohingya can be described in three categories as: pre-colonial, colonial, and postcolonial.

Pre-Colonial: As early as the $4^{\text {th }}$ century, an independent kingdom Arakan, led both by Muslim and Buddhist rulers, was established. Arakan was invaded by Mogul first and later by the Portuguese. In precolonial times, the independent kingdom of Arakan was populated by Muslim Arabic sailors from 788 to 810 , and afterwards by Bengalis from the $15^{\text {th }}$ to the $17^{\text {th }}$ centuries (Ahmad, 2014).

Allies of the Rohingya believe that they settled in Myanmar during the $7^{\text {th }}, 8^{\text {th }}$, or $9^{\text {th }}$ century and mixed with Bengalis, Persians, Moguls, Turks, and Pathans. During pre-colonial times, the Rohingyas and the remainder of the population in Arakan lived in harmony (Ullah, 2015; Thawnghmung, 2016).

Colonial: In 1784, the kingdom of Arakan was conquered by the Burmese and later by the British following the first Anglo-Burmese war of 1824-1826. The rift between the Rohingya and the Buddhist majority started date back to the beginning of British rule in 1824. The British under their "divide and rule" policy favored the Rohingya. In 1942, Japan invaded Burma and as a result of the British retreat communal violence erupted. Attacks were made against those groups that had benefited from British colonial rule. The region remained under Japanese control until British drove them out in 1945 (Tennery, 2015).

Prior to the Japanese invasion, the British, seeking to bolster support for their forces, promised the Rohingya for a separate land. During the World War II the Rohingyas sided with British but the Buddhists supported the Japan (Ullah, 2011). Following this war, the British government never fulfilled its promise to create a separate Muslim national area (Irish Centre for Human Rights, 2010).

Postcolonial: Burma got its independence in 1948 and the newly formed Government predominantly with the Buddhists denied citizenship to the Rohingyas and subjective discrimination invaded on the Rohingya community. Between the period of 1940 to 1947, Buddhist fundamentalist extremism was on the rise (HRW, 2012).

In 1962, just after a decade of Myanmar independence, a military coup turned the country into military State where democratic governance was woefully lacking. During the next 60 years of military rule, situation worsens for the Rohingya. The military authorities saw the Rohingya minority group as a threat to the national identity and the army started to commit numerous human rights violation to the Rohingyas (Devi, 2014).

In 1974, all the citizens of Burma got the national registration cards but the Rohingyas were allowed to get foreign registration cards. In 1978, the anti-Rohingya sentiment by the military ruler resulted in crackdown operation on Rohingyas which led to up to 250,000 Rohingyas flee to Bangladesh. Most of them returned to Myanmar with the repatriation agreement of 1978 (HRW, 2000). However, just after three years, Burma passed the 1982 Citizenship Law that denied citizenship to Rohingyas, as a result in an 


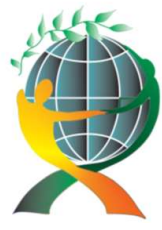

\author{
(online) $=$ ISSN $2285-3642$ \\ ISSN-L = 2285 - 3642 \\ Journal of Economic Development, Environment and People \\ Volume 8, Issue 2, 2019 \\ URL: http://jedep.spiruharet.ro \\ e-mail: office jedep@spiruharet.ro
}

estimated 800,000 Rohingyas in the north Rakhine become stateless (Tennery, 2015). In 1988, during the military rule, the State Law and Order Restoration Council (SLORC) established a number of new military cantonments at Rakhine State. At that time land was taken from the Rohingya without giving any compensation. As a result, the Rohingyas became 'homeless' in addition to 'stateless'. From 1982 the ongoing anti-Rohingya campaign and extreme circumstances resulted in a persistent exodus of the Rohingya to safer neighboring countries, where they reside as stateless people (Irish Centre for Human Rights, 2010; UNHCR \& WFP, 2012).

\title{
7. Exodus of Rohingya
}

First exodus of the Rohingya towards Bangladesh happened in 1978 but maximum of them repatriated to Myanmar (Amnesty International [AI], 2004). In 1990 general election, the Rohingya gave their support to Aung San Suu Kyi's National League for Democracy (NLD). Though NLD won the election but could not take the power due to the intervention of military junta and this also stepped up the crackdown on the Rohingyas. Between 1990 and 1991 military crackdown, additional rapes, forced labor caused another 250,000 Rohingyas to flee from Myanmar to Bangladesh. With the help of UNHCR a MOU was signed between Bangladesh and Myanmar in April 1992 under which Myanmar agreed to the return of those Rohingya refugees who could prove residency in Myanmar prior to their departure for Bangladesh. Under this deal only 50,000 Rohingyas could be repatriated and the rest took shelter at the camps of Cox's Bazar (UNHCR, 2007).

In 1996 and 1997, thousands of Rohingyas arrived in Cox's Bazar driven by high food prices in Myanmar and intensified forced labor imposed by Burmese security forces on the Rohingyas (Rohingya Influx since 1978, 2017). In 2012, renewed religious violence in Rakhine State resulted in another more than 100,000 Rohingya influx to Bangladesh (Australia Parliament Report, 2013). After 2012, some Rohingyas also attempted to reach Indonesia, Malaysia, and Thailand tragically, by boat (CNN, 2015). The displacement of Rohingyas from Myanmar continued in 2013, 2014, and 2015. The year 2015 is marked by UNHCR as "boat crisis" (UNHCR, 2017).

In October 2016, after attack at the army outposts by the Arakan Rohingya Salvation Army (ARSA) stateenforced violence took on the Rohingya even with greater ferocity. A brutal crackdown by the Burmese army caused many deaths and forced more than 75,000 Rohingya migrants to cross over to Bangladesh (HRW, 2018).

The largest, latest and shocking mass exodus of the Rohingya took place in the late August 2017. Within a month more than half a million Rohingyas fled to Bangladesh and took shelter in camps at Cox's Bazar. The influx gradually slowed down but did not stop (Reuters, 2018; UN, 2019). The UN has described the Myanmar military operations of 2017 against the Rohingya as a "textbook example of ethnic cleansing". The USA also declares the Myanmar moves against Rohingyas in August 2017 as 'ethnic cleansing'. Describing the atrocities against Rohingyas as 'genocide' a UN report calls for tribunal over Rohingya crisis (UN, 2017; Mohajan, 2018a).

\section{Defining Statelessness}

A stateless person means a person who is not recognized as a citizen by any State. A stateless person does not have any nationality. The 1954 Convention relating to the Status of Stateless Persons is the only 


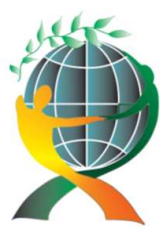

\author{
(online) $=$ ISSN $2285-3642$ \\ ISSN-L = $2285-3642$ \\ Journal of Economic Development, Environment and People \\ Volume 8, Issue 2, 2019 \\ URL: http://jedep.spiruharet.ro \\ e-mail: office jedep@spiruharet.ro
}

international treaty aimed specifically at regulating the standard of treatment for stateless persons. According to the Article 1 of the 1954 Convention "a stateless person" means a person who is not considered as a national by any State under the operation of its law. In simple terms, this means that a stateless person does not have a nationality of any country. Some people are born stateless, but others become stateless (UNHCR, 1954).

There are two international conventions relating to the statelessness. One is 1954 Convention relating to the status of stateless persons and another one is 1961 Convention relating to the reduction of statelessness. Neither Myanmar nor Bangladesh is the signatory of these two conventions (The Daily Star, 2017).

\title{
9. Rohingya Statelessness
}

Article 15 of the Universal Declaration of Human Rights (UDHR) states that everyone has the right to a nationality and that none shall be arbitrarily deprived of his nationality nor denied the right to change his nationality. So, it can be said that Article 15 of the UDHR establishes the bedrock legal relationship between individuals and States. But it is not followed with the Rohingya community of Myanmar (UDHR, 1948).

There are three groups of stateless people originating from Rakhine State of Myanmar as; i) the native born Rohingyas in Myanmar but considered as indigenous without citizenship, ii) the Rohingyas living in abroad (Bangladesh, India, Pakistan, etc.), and iii) the Rohingya children born in camps (The International Observatory on Statelessness, 2019).

Since Burma's independence in 1948 the Rohingyas are gradually been excluded from the right to the citizenship. After independence the new Government passed the Historic Union Citizenship Act having 135 official ethnic groups. But the Rohingyas were not considered as ethnic group (Fortify Rights, 2015). The act, however, did allow those whose families had lived in Myanmar for at least two generations to apply for identity cards. At that time some Rohingyas got citizenship and their ethnicity was included in 1961 census (Gibson, 2016). But situation changes dramatically when the military junta came to power in 1962 and attacks the Rohingya by depriving them from their rights. The military government dissolved all the political and social organizations of Rohingyas (Council on Foreign Relations, 2018). The Emergency Immigration Act-1974 stripped the Rohigyas from the Burmese nationality. In 1974, all citizens in Burma were required to get national registration cards, but the Rohingyas were only allowed to obtain foreign registration cards (Cheung, 2012).

In 1977, the military Government initiated an identification card check census program titled Nagamin (King of Dragons) in which all citizens of Burma were required to register but the Rohingyas were barred from doing so (Fortify Rights, 2015). By 1982, a new citizenship law was passed that prevented the Rohingya from easily accessing full citizenship, rendering many of them stateless. Under the 1982 Citizenship Law, the Rohingya were declared "non-national" or "foreign residents." This law designated three categories of citizens: 1) full citizens, 2) associate citizens, and 3) naturalized citizens. None of the categories applies to the Rohingya, as they are not recognized as one of the 135 ethnic groups by the GoM (Refworld, 2009). 


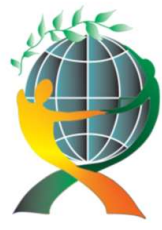

\author{
(online) $=$ ISSN $2285-3642$ \\ ISSN-L = $2285-3642$ \\ Journal of Economic Development, Environment and People \\ Volume 8, Issue 2, 2019 \\ URL: http://jedep.spiruharet.ro \\ e-mail: office jedep@spiruharet.ro
}

In 1989, color-coded Citizens Scrutiny Cards (CRCs) were introduced in Burma: pink cards for full citizens, blue for associate citizens, and green for naturalized citizens. None of these cards were issued to the Rohingyas (Islam, 2012). In 1995, in response to UNHCR's intensive advocacy efforts to document the Rohingyas, the Burmese authorities started issuing the Rohingyas with a Temporary Registration Card (TRC), a white card, pursuant to the 1949 Residents of Burma Registration Act. But the TRC does not mention the bearer's place of birth and cannot be used to claim citizenship (Ullah, 2015).

In 2014 census of Myanmar, the Rohingyas were referred as 'Bengali migrants' and excluded from the counting. In that census, GoM initially tried to identify the Rohingya, but Buddhist nationalists threatened to boycott the census. Then the government decided to register the Rohingya as Bengali (Green et al., 2015). The white cards are given to Rohingyas in 1995 for the right to vote in the 2010 general election and the 2012 bi-election. But these white cards were subsequently revoked in early 2015, barring card holders from voting or standing for parliament in the 2015 election (Green et al., 2015).

The transition to civilian government in Myanmar in 2012 and then in 2016 has further wrinkled the rights of the Rohingya. More rounds of citizenship verification were initiated, starting with President Thein Sein from 2012-2015 and continuing with Aung San Suu Kyi in 2016. Both have largely failed due to restrictions on self-identifying as Rohingya, distrust from affected populations, unclear processes and opposition from anti-Rohingya Buddhist nationalist groups (Refworld, 2016).

The issue of statelessness was also included in the final report from The Advisory Commission on Rakhine State, which formed on August 2016 as an independent body chaired by former UN chief Kofi Annan with the objective of providing recommendations on the troubled region to the GoM (Amnesty International, 2017).

In 2012, the Myanmar de facto leader Aung San Suu Kyi said that she does not know that the Rohingya could be regarded as citizen of Myanmar. In October 2013, she was interviewed by BBC Journalist Mishal Husain about the plight of the Rohingya in Myanmar. After a tense exchange with BritishPakistani news presenter Mishal Husain, she reportedly said off air, "No one told me I was going to be interviewed by a Muslim."

As a stateless people, Rohingyas are in a sense outlawed of the Myanmar laws. It may be said that, policies and politics of Myanmar are dynamic, and different generals and presidents of Myanmar have taken the politics concerning minorities and stateless in Myanmar. But no person of power has tried to give citizenship back to the Rohingyas, and they have remained stateless. From after the independence of Myanmar in 1948 or from starting of junta Government in 1962 or from the inauguration of civilian Government led by Aung San Suu Kyi in 2016. The statelessness of the Rohingya is going on and till today the Rohingyas have no nationality, no passports, and no valid papers (Rahman, 2018).

\title{
10.The Lost Generation
}

The term 'lost generation' was introduced by a modernist American writer Gertrude Stein (1874-1946) to refer to a group of American literary notables who came from America lived in Paris in the 1920s and 1930s. The term is used more generally to the generation of men and women who came of age during or 


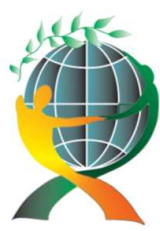

\author{
(online) $=$ ISSN $2285-3642$ \\ ISSN-L = $2285-3642$ \\ Journal of Economic Development, Environment and People \\ Volume 8, Issue 2, 2019 \\ URL: http://jedep.spiruharet.ro \\ e-mail: office jedep@spiruharet.ro
}

immediately after the World War I. The generation was "lost" in the sense that its inherited values were no longer relevant in the post War World I (Britannica, 2019).

The term 'lost generation' was made popular by Nobel laureate writer Ernest Hemingway (1899-1961) who included the term as an epigraph in his classic 1926 novel The Sun Also Rises. In literature, the term also refers to a group of well-known American authors and poets including Ernest Hemingway, Gertrude Stein, F. Scott Fitzgerald, and T. S. Elliot, who left the USA to take part in the literary culture of Europe after World War I. Though they are known as lost generation writers but they have prominent presence in the $20^{\text {th }}$ century literature (Hemingway, 1926).

\title{
11. Rohingya Children-the Lost Generation
}

The right to a nationality is addressed in a number of international law/act, including the International Covenant on Civil and Political Rights-1966 in which the right of a child is established. Article 24(3) of the International Covenant on Civil and Political Rights 1966 states, "Every child has the right to acquire a nationality" (International Covenant on Civil and Political Rights, 1966).

A child's right to a nationality is also recognized by the UN Convention on the Rights of the Child1989. Articles 7 and 8 of this Convention states (Convention on the Rights of the Child, 1989):

Article 7.1: The child shall be registered immediately after birth and shall have the right from birth to a name, the right to acquire a nationality...

Article 7.2: States parties shall ensure the implementation of these rights in accordance with their national law and their obligations under the relevant international instruments in this field, in particular where the child would otherwise be stateless.

Article 8.1: States parties undertake to respect the right of the child to preserve his or her identity, including nationality...

Article 8.2: Where a child is illegally deprived of some or all of the elements of its identity. States parties shall provide appropriate assistance and protection, with a view to re-establishing speedily its identity.

Myanmar ratified both International Covenant on Civil and Political Rights 1966 and the UN Convention on Rights of the Child 1989 but the GoM deprived the Rohingya children of that right (Amnesty International, 2004).

Again the GoM refuses to give citizenship to children born outside the country to Burmese parents who left or fled persecution. Children born in Bangladesh, India or in other countries of Burmese descent do not have birth certificates and the parents do not have citizenship papers. Neither recognized by the GoM nor wanted by the Government, who gave them shelter the Rohingya children become effectively stateless as like their parents (Lewa, 2009).

The Rohingya children both in Myanmar and in the camps of Bangladesh are lack of proper education as reported by UNICEF. The Rohingya youth who remain in Rakhine State of Myanmar faced restriction to go to school, and in Bangladesh the children who lived in camps also do not have proper education facilities. The UNICEF report on 23 August 2018 warned that the new generation of the Rohingya may become 'lost 


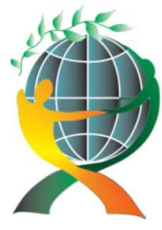

\author{
(online) $=$ ISSN $2285-3642$ \\ ISSN-L = $2285-3642$ \\ Journal of Economic Development, Environment and People \\ Volume 8, Issue 2, 2019 \\ URL: http://jedep.spiruharet.ro \\ e-mail: office jedep@spiruharet.ro
}

generation' due to the lack of the life skills they need to grow up. The UNICEF report released in New York on 23 August 2018 revealed that the international community needs to do more to prevent some half a million youngsters "falling prey to despair and frustration". The UNICEF report marking one year of the huge influx of the Rohingya coming to Bangladesh warned that the Rohingya children living in the camps of Cox's Bazar face a bleak future with denial of chance of proper education. As a result the report said, "The world may face the very real danger of seeing a 'lost generation' of Rohingya children" (UNICEF, 2018).

Again in a report of the Burmese Rohingya Organization UK (BROUK) stated that a generation of the Rohingya may be lost due to a lack of education for children and the youth at camps for the displaced in Bangladesh and Myanmar. The BROUK report said that while aid groups had made "heroic efforts" to overcome the Rohingya crisis but there had in fact been little long-term planning in relation to the education of Rohingya youths. The report also said that international and local NGOs as well as communitybased organizations have already set up educations centers in the 27 refugee camps of the Rohingya but the quality of these educational centers depend on who is running them (BROUK, 2018).

The president of the BROUK, Tun Khin said that, "Now, more than ever, we need educated Rohingya who can act as leaders for the community, but as long as education remains severely restricted this will be impossible, and so we are facing the prospect of a lost generation" (Al Jazeera, 2018).

\title{
12. Conclusion
}

The Rohingyas are not recognized as citizen by the GoM though they lived for generations there. Living in Myanmar or other countries Rohingyas are now living with stateless status. The international community are now aware of the 'statelessness' status of the Rohingya. At present the number of Rohingyas living outside of the Myanmar State is more than the numbers living inside the Myanmar. The present position is like that the Rohingyas are on the face of extinction in Myanmar. The new generation of the Rohingya living in various camps is now facing the danger of 'lost generation' as they are not getting proper education and other living facilities. The international community should come forward to save the ethnic Rohingya community. We should tune up with the words of UN Chief Antonio Guterres-"Rohingya cannot become forgotten victims."

\section{References}

[1] Abdelkader, E. (2014). Myanmar's Democracy Struggle: The Impact of Communal Violence upon Rohingya Woman and Youth. Pacific Rim Law \& Policy Journal, 23(3), 511-542.

[2] Ahmad, I. (2014). The Plight of the Stateless Rohingyas. The University Press Limited: Dhaka, Bangladesh.

[3] Al (2017). Caged without a Roof. https://www.amnesty.org/download/Documents/ASA1674842017ENGLISH.PDF

[4] Al Jazeera (2018). Rohingya Facing 'Lost Generation' of Children Out of School. 13 December $2018 . \quad$ http: www.aljazeera.com/news/2018/12/rohingya-facing-lost-generation-children-school-181212082048462.html

[5] Amnesty International, Al (2004). Myanmar the Rohingya Minority-Fundamental Rights Denied. https://www.amnesty.org/download/Documents/92000/asa160052004en.pdf 


\author{
(online) $=$ ISSN $2285-3642$ \\ ISSN-L = 2285 - 3642 \\ Journal of Economic Development, Environment and People \\ Volume 8, Issue 2, 2019 \\ URL: http://jedep.spiruharet.ro \\ e-mail: office jedep@spiruharet.ro
}

[6] Anand, B. N., \& Khanna, T. (2000). Do Firms Learn to Create Value? The Case of Alliances. Strategic Management Journal, 21(3), 293-315.

[7] Australia Parliament Report (2013). Myanmar: Sectarian Violence in Rakhine Issues. Humanitarian Consequences, and Regional Responses. https://www.aph.gov.au/About Parliament/Parliamentary Departments/Parliamentary Library/pubs/rp/rp131 4/Myanmar

[8] Bellamy, A. (2016). Myanmar: The Oxford Handbook of the Responsibility to Protect. Oxford University Press, Oxford, UK.

[9] Britannica (2019). Lost Generation. Encyclopedia Britannica. Adam Augusttyn, Patricia Bauer et al. (Eds.). https://www.britannica.com/topic/Lost-Generation

[10] BROUK (2018). The Right to Education Denied for Rohingya Refugees in Bangladesh. The UK Report, 13 December 2018. https: //burmacampaign.org.uk/rohingya-denied-access-to-education-in-myanmar-and-bangladesh/theright-to-education-denied-for-rohingya-refugees-in-bangladesh/

[11] Cheung, S. (2012). Migration Control and the Solutions Impasse in South and Southeast Asia: Implications from the Rohingya Experience. Journal of Refugee Studies, 25(1), 50-70.

[12] CNN (2015). Lost at Sea, Unwanted: The Plight of Myanmar's Rohingya Boat People. May 20, 2015. https://edition.cnn.com/2015/05/19/asia/rohingya-refugee-ships-explainer/index.html

[13] Convention on the Rights of the Child (1989). Convention on the Rights of the Child. art. 7, Nov. 20, 1989, 1577 U.N.T.S. https://www.ohchr.org/documents/professionalinterest/crc.pdf

[14] Council on Foreign Relations (2018). The Rohingya Crisis. Council on Foreign Relations, December 5, 2018. https://www.cfr.org/backgrounder/rohingya-crisis

[15] Demographics of Myanmar (2018). Population of the Republic of the Union of Myanmar in 2018.

[16] Devi, K. S. (2014). Myanmar under the Military Rule 1962-1988. International Research Journal of Social Sciences, $3(10), 46-50$.

[17] Ene, A.S. (2016). Understanding the Notion of State Aid and its Correct Application. Annals of Spiru Haret University, 7(6), 95-110.

[18] Fortify Rights (2015). Persecution of Rohingya Muslims. October 21, 2015. https://www.fortifyrights.org/downloads/Yale Persecution of the Rohingya October 2015.pdf

[19] Fumagalli, M. (2018). Myanmar 2017: The Rohingya Crisis between Radicalisation and Ethnic Cleansing. Asia Maior, XXVIII, 227-243. https: //research-repository.standrews.ac.uk/bitstream/handle/10023/14679/Fumagalli 2018 AM Myanmar2017 VoR.pdf?sequence=1\&isAll owed $=\mathrm{y}$

[20] Gibson, T. (Ed.) (2016). Rohingyas-Insecurity and Citizenship in Myanmar. Thaksin University Press, Thailand. http://www.iid.org/uploads/6/2/0/6/6206024/rohingya.pdf

[21] Green, P., MacManus, T., \& de la Cour Venning, A. (2015). Countdown to Annihilation: Genocide in Myanmar. London: International State Crime Initiative. http://statecrime.org/data/2015/10/ISCl-Rohingya-ReportPUBLISHED-VERSION.pdf

[22] Haque, M. M. (2017). Rohingya Ethnic Muslim Minority and the 1982 Citizenship Law in Burma. Journal of Muslim 


\author{
(online) $=$ ISSN $2285-3642$ \\ ISSN-L = $2285-3642$ \\ Journal of Economic Development, Environment and People \\ Volume 8, Issue 2, 2019 \\ URL: http://jedep.spiruharet.ro \\ e-mail: office jedep@spiruharet.ro
}

Minority Affairs, 37(4), 454-469.

[23] Hemingway, E. (1926). The Sun Also Rises. New York: Modern Library.

[24] Holliday, M. I. (2014). Addressing Myanmar's Citizenship Crisis. Journal of Contemporary Asia, 44(3), 404-421.

[25] Human Rights Watch, HRW (2000). Living in Limbo: Burmese Rohingyas in Malaysia. New York, NY, USA.

[26] HRW (2012). The Government Could have Stopped This. New York, NY, USA. http://www.hrw.org/reports/2012/08/01/government-could-have-stopped.

[27] HRW (2018). The Pushback against the Populist Challenge. World Report, 2018. Human Rights Watch, 2018, USA.

[28] International Covenant on Civil and Political Rights (1966). International Covenant on Civil and Political Rights. $\begin{array}{llllllll}\text { art.24(3), Dec. } & \text { 19,1966, } & 993 & \text { U. } & \text { N. } & \text { T. } & \text { S. } & \text { 3. }\end{array}$ citizenship.eu/InternationalDB/docs/Art\%2024\%2026\%20ICCPR.pdf

[29] Irish Centre for Human Rights (2010). Crimes against Humanity in Western Burma: The Situation of the Rohingyas. Irish Centre for Human Rights: Connacht, Ireland.

[30] Islam, N. (1999). The Rohingya Problem, Arakan Rohingya National Organisation (ARNO). Arakan (Burma).

[31] Islam, N. (2012). Rohingya Tangled in Burma Citizenship Politics. Kaladan Press Network. http://www.burmalibrary.org/docs21/Nurul_Islam-2012-05-30Rohingya_tangled_in_Burma_citizenship_politics-en.pdf

[32] Kosem, S., \& Saleem, A. (2016). Religion, Nationalism, and the Rohingya's Search for Citizenship in Myanmar. In Robert Mason (Ed.), Muslim Minority-State Relations: Violence, Integration, and Policy. Palgrave Macmillan, Basingstoke, UK.

[33] Kyaw, N. N. (2017). Unpacking the Presumed Statelessness of Rohingyas. Journal of Immigrant \& Refugee Studies, 15(3), 269-286. https://doi.org/10.1080/15562948.2017.1330981

[34] Lewa, C. (2009). Northern Arakan: An Open Prison for the Rohingya in Burma. Forced Migration Review, 32, 1113. https://www.fmreview.org/sites/fmr/files/FMRdownloads/en/statelessness/lewa.pdf

[35] Milton, A. H., Rahman, M., Hussain, S., Jindal, C., Choudhury, S., Akter, S., Ferdousi, S., Mouly, T. A., Hall, J., \& Efird, J. T. (2017). Trapped in Statelessness: Rohingya Refugees in Bangladesh. International Journal of Environmental Research and Public Health, 14(8), pii: E942, 1-8.

[36] Mohajan, H. K. (2018a). The Rohingya Muslims in Myanmar are Victim of Genocide! ABC Journal of Advanced Research, 7(1), 59-72.

[37] Mohajan, H. K. (2018b). History of Rakhine State and the Origin of the Rohingya Muslims. IKAT: The Indonesian Journal of Southeast Asian Studies, 2(1), 19-46.

[38] Mohajan, H. K. (2018c). Qualitative Research Methodology in Social Sciences and Related Subjects. Journal of Economic Development, Environment and People, 2(1), 19-46.

[39] Mohajan, H. K. (2019). Knowledge Sharing among Employees in Organizations. Journal of Economic Development, Environment and People, 8(1), 52-61.

[40] Parashar, A., \& Alam, J. (2018). The National Laws of Myanmar: Making of Statelessness for the Rohingya. International Migration, 57(1), 94-108. http://doi.org/10.1111/imig.12532

[41] Rahman, M. M. (2017). Pope Uttered the Term 'Rohingya'. The News Report is Prepared by Md. Mahbubur 


\author{
(online) $=$ ISSN $2285-3642$ \\ ISSN-L = $2285-3642$ \\ Journal of Economic Development, Environment and People \\ Volume 8, Issue 2, 2019 \\ URL: http://jedep.spiruharet.ro \\ e-mail: office jedep@spiruharet.ro
}

Rahman, News Producer, BTV. https://youtu.be/OeLDAQ0P7sQ

[42] Rahman, M. M. (2018). News Reports on Rohingya Crisis. The News Report is Prepared by Md. Mahbubur Rahman, News Producer, BTV. //www.youtube.com/playlist?list=PLydyw2P14fp3aMxfa2A8pParGa3RZzH8M

[43] Refworld (2009). Nationality Rights for All. March 2009. https://www.refworld.org/pdfid/49be193f2.pdf

[44] Refworld (2016). Rohingya Policies and Restrictions under Myanmar's New Government. October $26,2016$. https://www.refworld.org/pdfid/5825f3ba4.pdf

[45] Remenyi, D. S. J., Swartz, E., Money, A., \& Williams, B. (1998). Doing Research in Business and Management: An Introduction to Process and Method. SAGE Publications, London.

[46] Reuters (2018). Myanmar Says Police Attacked as Western Fighting Displaces Thousands. Reuters, 02 January 2019. https://af.reuters.com/article/worldNews/idAFKCN1OWOAP

[47] Rohingya Influx since 1978 (2017). History of Rohingya in Bangladesh. Background on the Context in Bangladesh. Review-Thematic Report. https://www.acaps.org/sites/acaps/files/slides/files/20171211 acaps rohingya historical review.pdf

[48] Ruland, A. (2017). Myanmar's Rohingya Problem in Context. ISPSW Strategy Series, Germany. http: //www.ispsw.com/wp-content/uploads/2017/05/485 R\%C3\%BCland.pdf

[49] Tennery, A. (2015). Why is No One Helping Myanmar's Rohingya? Thomson Reuters: New York, NY, USA.

[50] Thawnghmung, A. M. (2016). The Politics of Indigeneity in Myanmar: Competing Narratives in Rakhine State, Asian Ethnicity, 17(4), 527-547. https://doi.org/10.1080/14631369.2016.1179096

[51] The Daily Star (2017). Resettling Rohingyas and International Law. March $14,2017$. https://www.thedailystar.net/law-our-rights/rights-advocacy/resettling-rohingyas-and-international-law$\underline{1375510}$

[52] The International Observatory on Statelessness (2019). The International Observatory on Statelessness: Burma/Myanmar. http://www.nationalityforall.org/burma-myanmar

[53] Universal Declaration of Human Rights, UDHR (1948). Universal Declaration of Human Rights. United Nations, December 10, 1948 UNGA Res 217 A(III).

[54] Ullah, A. A. (2011). Rohingya Refugees to Bangladesh: Historical Exclusions and Contemporary Marginalization. Journal of Immigrant \& Refugee Studies, 9(2), 139-161.

[55] Ullah, A. A. (2015). Playing with Color of Cards. https://www.thestateless.com/2015/08/playing-with-color-ofcards.html

[56] UN (2017). Atrocities against Rohingya as Ethnic Cleansing. A News Report Prepared by Md. Mahbubur Rahman Broadcast through BTV. October 26, 2017. https://youtu.be/me_ToMMBew

[57] UN (2018). UNICEF Warns of 'Lost Generation' of Rohingya Youth, One Year after Myanmar Exodus. UN News, 22 August, 2017. https://news.un.org/en/story/2018/08/1017632

[58] UN (2019). Thousands Flee from Rakhine Since Last Month Due to Clashes. English News BTV on Air, 03 January 2019. https://youtu.be/iBnYt2WUpVY

[59] United Nations High Commissioner for Refugees, UNHCR (1954). Text of the 1954 Convention Relating to the 


\author{
(online) $=$ ISSN $2285-3642$ \\ ISSN-L = 2285 - 3642 \\ Journal of Economic Development, Environment and People \\ Volume 8, Issue 2, 2019 \\ URL: http://jedep.spiruharet.ro \\ e-mail: office jedep@spiruharet.ro
}

Status of Stateless Persons. United Nations High Commissioner for Refugees. https://www.unhcr.org/unconventions-on-statelessness.html

[60] UNHCR (2007). Bangladesh: Analysis of Gaps in the Protection of Rohingya Refugees. https://bit.ly/2pdvB4x

[61] UNHCR (2017). Over 168,000 Rohingyas Likely Fled Myanmar since 2012. 03 May 2017. https://www.unhcr.org/news/latest/2017/5/590990ff4/168000-rohingya-likely-fled-myanmar-since-2012-unhcrreport.html

[62] UNHCR \& WFP (2012). The Contribution of Food Assistance to Durable Solutions in Protracted Refugee Situations. Its Impact and Role in Bangladesh: A Mixed Method Impact Evaluation. UNHCR \& WFP: Rome, Italy.

[63] UNICEF (2018). Investment in Education Desperately Needed to Avert Lost Generation of Rohingya Children. UNICEF Report, 23 August 2018. https://www.unicef.org/press-releases/investment-education-desperatelyneeded-avert-lost-generation-rohingya-children

[64] Yin, K. M. (2005). Salience of Ethnicity among Burman Muslims: A Study in Identity Formulation. Intellectual Discourses, 13(2), 168-169.

[65]Zawacki, B. (2013). Defining Myanmar's Rohingya Problem. Human Rights Brief, 20(3), 18-25. https://digitalcommons.wcl.american.edu/cgi/viewcontent.cgi?article=1873\&context=hrbrief 